\title{
Growth regulators' effect on crested wheatgrass forage yield and quality
}

\section{LARRY M. WHITE}

\section{Abstract}

If crested wheatgrass [Agropyron desertorum (Fisch.) Schult.] could be maintained in an immature growth stage, it would improve forage quality and thus extend the graxing season. In 1981 and 1982, plant growth regulators were applied to crested wheatgrass $0,2,4$, and 6 weeks after first floral primordium initiation to determine which compound, date, and rate of application would maximize forage quality yet minimize reduction of forage yield when harvested at seed ripe stage. Mefluidide [N-(2,4-dimethyl-5\{[(trifluoromethyl)-sulfonyl $] a m i n o\}$ phenyl)acetamide] at 4 rates $[0.0,0.28,0.56$, and $0.84 \mathrm{~kg} / \mathrm{ha}$ active ingredient (a.i.)], maleic hydrazide (MH) (1,2-dihydro-3,6-pyridazinedione) at $4.5 \mathrm{~kg} / \mathrm{ha}$ aj., and MH (3.36 kg/has.j.) phus chlorfinirenol (methyl-2-chloro-9hydroxynuorene-9-carboxylate) at $1.12 \mathrm{~kg} / \mathrm{ha}$ a.i. were applied to crested wheatgrass growing on a Shambo loam (Typic Haploborolls) in northeast Montana. Application of MH or MH plus chlorflurenol generally gave a similar response in heading, forage yield, CP, and in vitro organic matter digestibility on a dry matter basis (IVDOMD) as did melnuidide at $0.56 \mathrm{~kg} / \mathrm{ha}$. Mefluidide $(0.56 \mathrm{~kg} / \mathrm{ha})$ applied 2 weeks after first floral primordium initiation decreased heading 80 and $95 \%$, decreased forage yield 20 and $30 \%$, increased CP 1.7 and 2.3 percentage units, and increased IVDOMD 1.8 to 4.2 percentage units compared to untreated, depending upon year.

Key Words: Agropyron desertorum, heading, crude protein, in vitro digestibility, melfuidide, maleic hydrazide, chlorflurenol, foral primordium, growth stage, application rates

Crested wheatgrass [Agropyron desertorum (Fisch.) Schult.] provides high quality forage during early spring, but forage quality (White and Wight 1981) and livestock weight gains decrease as the growing season progresses (Campbell 1961). If crested wheatgrass could be maintained in an immature growth stage, it would improve forage quality and thus extend the grazing season.

Haferkamp et al. (1987) found that application of melfluidide [N-(2,4-dimethyl-5-\{(trifluoromethyl)-sulfonyl]amino\}phenyl) acetamide] to crested wheatgrass near floral differentiation increased crude protein (CP) 1.8 to 1.9 percentage units and in vitro digestible organic matter by 3.0 to 4.0 percentage units. However, this decreased forage production by 20 to $60 \%$ depending upon rate. The effect of timing of melfluidide application was not determined. Field and Whitford (1982) found that date of melfluidide application affected reductions in dry matter production of perennial ryegrass (Lolium perenne $\mathbf{L}$.) depending upon plant growth stage. Other growth regulators such as maleic hydrazide (MH) (1,2dihydro-3,6-pyridazinedione) and MH plus chlorflurenol (methyl2-chloro-9-hydroxyfluorene-9-carboxylate) have effectively reduced heading of grasses along roadsides (Wakefield and Dore 1973), and may, therefore, be effective in increasing forage quality.

The study objective was to determine the effects of growth regulators [melfluidide (4 rates), $\mathrm{MH}$, and $\mathrm{MH}$ plus chlorflurenol] and application date on heading, forage yield, $C P$, and in vitro

\footnotetext{
Author is range scientist, USDA-ARS, Southern Plains Range Research Station, 2000-18th St., Woodward, Okla. 73801. At the time of research, author was a range scientist, USDA-ARS, Northern Plains Soil and Water Research Center, Sidney, Mont

This article is a contribution from USDA, Agricultural Research Service.

Manuscript accepted 4 August 1988.
}

digestibility of crested wheatgrass when harvested at seed ripe stage during early August.

\section{Materials and Methods}

The study was conducted during 1981 and 1982 on a stand of standard crested wheatgrass seeded in the early $1960 \mathrm{~s}$. The study site was $25 \mathrm{~km}$ north of Sidney, Mont., at an elevation of $640 \mathrm{~m}$ $(2,100 \mathrm{ft})$ on a silty range site. The soil is a Shambo loam (fineloamy, mixed, Typic Haploborolls). A single application of ammonium nitrate was made in early December 1980 at $54 \mathrm{~kg}$ $\mathrm{N} /$ ha. Average annual precipitation is $350 \mathrm{~mm}$, with $21 \%$ received from October through March, 44\% from April through June, and 35\% from July through September. Precipitation from October 1980 through May 1981 averaged $40 \%$ of normal each month, while June 1981 was twice normal. Precipitation from October through December 1981, January through March 1982, April through May, and June through September was $99,232,13$, and $96 \%$ of normal, respectively. January and July long-term mean temperatures are -13 and $20^{\circ} \mathrm{C}$, respectively, and the average frost-free period is 122 days.

Mefluidide $(0.0,0.28,0.56$, and $0.84 \mathrm{~kg} /$ ha of active ingredient [a.i.]), MH alone (4.5 kg/ha a.i.), and $\mathrm{MH}(3.36 \mathrm{~kg} / \mathrm{ha}$ a.i.) plus chlorflurenol $(1.12 \mathrm{~kg} / \mathrm{ha}$ a.i.) were applied to a new set of plots on 3 dates in 1981 in a $3 \times 6$ factorial arrangement of treatments (plots 1.5 by $3 \mathrm{~m}$ ) in 4 randomized complete blocks. Crested wheatgrass had not reached the early boot stage by the third application date so a fourth application was made on a set of plots adjacent to the first set. In 1982, the treatment area was expanded on the same site to include a $4 \times 6$ factorial arrangement of treatments. The first application of growth regulators each year was applied within the same week that the floral primordia were initiated as determined by weekly examination of nearby plants. Growth regulators were applied to a new set of plots every 2 weeks thereafter. The fourth application was made when crested wheatgrass was 1 and $20 \%$ headed in 1981 and 1982, respectively. Application dates were 7 April, 22 April, 4 May, and 18 May 1981; and 28 April, 12 May, 25 May, and 10 June 1982. Growth regulators were applied in water using 3 flat-fan nozzles ( 8004 ) mounted on a bicycle sprayer pressurized with $\mathrm{CO}_{2}$ at $207 \mathrm{kPa}$ (30 psi) moving at $3.2 \mathrm{~km} / \mathrm{hr}(2$ miles/hr) and delivering 469 and $425 \mathrm{~L} / \mathrm{ha}$ during 1981 and 1982. Bromoxynil (3,5-dibromo-4-hydroxybenzonitrile) was applied in water on 7 May 1982 at $0.5 \mathrm{~kg} / \mathrm{ha}$ a.i. with flat-fan nozzles (80015) delivering $210 \mathrm{~L} /$ ha to control yellow sweetclover (Melilotus officinalis Lam.) in the plots.

Crested wheatgrass seed heads were counted each year in 2 quadrats $(0.5$ by $0.63 \mathrm{~m})$ within each plot when seed was ripe during early August. Forage was then harvested from a 1.0 by $2.0-\mathrm{m}$ sample area to a 5-cm stubble height. Forage from the remainder of the plot was removed a few days later. Plant material was dried at $60^{\circ} \mathrm{C}$ and ground to pass a $1-\mathrm{mm}$ screen before analysis. Nitrogen concentration was determined by the macro-Kjeldahl method and multiplied by 6.25 to estimate CP. In vitro organic matter digestibility on a dry matter basis (IVDOMD) was determined by a modification of the Tilley and Terry two-stage method (White et al. 1981). 
Table 1. Probability of F test for linear, quadratic, and cubic interaction for 3 and 4 application dates in 1981 and 1982 with 4 rates of menuidide $(0,0.28,0.56$, and $0.84 \mathrm{~kg} / \mathrm{ha})$ application on number of heads, forage yield, CP, and IVDOMD of crested whentgrass grown near Sidney, Montana.

\begin{tabular}{|c|c|c|c|c|c|c|c|c|}
\hline \multirow[b]{2}{*}{ Interaction } & \multicolumn{2}{|c|}{ Heads } & \multicolumn{2}{|c|}{$\begin{array}{c}\text { Forage } \\
\text { yield }\end{array}$} & \multicolumn{2}{|c|}{ CP } & \multicolumn{2}{|c|}{ IVDOMD } \\
\hline & 81 & 82 & 81 & 82 & 81 & 82 & 81 & 82 \\
\hline Date $X$ rate & $<.01$ & .01 & $<.01$ & .06 & $<.01$ & $<.01$ & .07 & $<.01$ \\
\hline $\begin{array}{l}\mathbf{D}_{1} \times \mathbf{R}_{\mathbf{l}^{1}} \\
\mathbf{D}_{1} \times \mathbf{R}_{\mathrm{q}} \\
\mathbf{D}_{1} \times \mathbf{R}_{\mathrm{c}}\end{array}$ & $\begin{array}{r}<.01 \\
.54 \\
.23\end{array}$ & $\begin{array}{r}<.01 \\
.20 \\
.96\end{array}$ & $\begin{array}{r}<.01 \\
.53 \\
.06\end{array}$ & $\begin{array}{l}.85 \\
.47 \\
.88\end{array}$ & $\begin{array}{r}<.01 \\
.64 \\
.60\end{array}$ & $\begin{array}{l}.06 \\
.68 \\
.80\end{array}$ & $\begin{array}{r}<.01 \\
.55 \\
.74\end{array}$ & $\begin{array}{r}<.01 \\
<.01 \\
.31\end{array}$ \\
\hline $\begin{array}{l}\mathbf{D}_{\mathrm{q}} \times \mathbf{R}_{\mathbf{l}} \\
\mathbf{D}_{\mathrm{q}} \times \mathbf{R}_{\mathbf{q}} \\
\mathbf{D}_{\mathrm{q}} \times \mathbf{R}_{\mathrm{c}}\end{array}$ & $\begin{array}{r}.04 \\
<.01 \\
.03\end{array}$ & $\begin{array}{l}.75 \\
.09 \\
.22\end{array}$ & $\begin{array}{l}.14 \\
.79 \\
.90\end{array}$ & $\begin{array}{r}<.01 \\
.10 \\
.68\end{array}$ & $\begin{array}{r}<.01 \\
.74 \\
.23\end{array}$ & $\begin{array}{r}<.01 \\
.86 \\
.36\end{array}$ & $\begin{array}{l}.06 \\
.39 \\
.80\end{array}$ & $\begin{array}{l}.64 \\
.60 \\
.08\end{array}$ \\
\hline $\begin{array}{l}D_{c} \times R_{1} \\
D_{c} \times R_{a} \\
D_{c} \times R_{c}\end{array}$ & - & $\begin{array}{l}.99 \\
.03 \\
.28\end{array}$ & - & $\begin{array}{l}.05 \\
.11 \\
.60\end{array}$ & - & $\begin{array}{l}.66 \\
.21 \\
.04\end{array}$ & 二- & $\begin{array}{r}.18 \\
<.01 \\
.05\end{array}$ \\
\hline
\end{tabular}

$I_{1}=$ linear, $q=$ quadratic, $c=$ cubic response

Precipitation was measured daily at the site from April through October in a standard $20-\mathrm{cm}$ recording rain gauge. Precipitation data from November through March and daily air temperatures from February through June were obtained from an official weather station located at Sidney, Mont. Degree days (accumulated daily mean air temperature above $3^{\circ} \mathrm{C}$ threshold) accumulated from the first of February through June were calculated to determine if there was a difference between years when growth regulators were applied.

The data were first analyzed with a 3 date by 6 treatment and $4 X$ 6 factorial analysis of variance the first and second years, respectively, using a randomized complete block design to determine if different kinds of growth regulators had a significant effect on heading, forage yield, CP, and IVDOMD. The analysis showed a significant or highly significant date by treatment interaction for all variables measured. Since $F$ test was significant, the least significant difference (LSD) test at $0.05 \%$ was used to determine: (1) if the response from application of $0.56 \mathrm{~kg} / \mathrm{ha}$ of mefluidide differed from that of $\mathrm{MH}$, and (2) if $\mathrm{MH}$ differed from that of $\mathrm{MH}$ plus chlorflurenol. The data from the fourth application in 1981 were analyzed separately since they were not included in the same blocks as the first $\mathbf{3}$ dates. All treatment differences reported are significant at the $P \leq 0.05$ probability level unless otherwise stated.
The response surface showing date and rate changes for mefluidide was determined using a $3 \times 4$ and $4 \times 4$ factorial analysis of variance the first and second years, respectively. The interaction treatment sum of squares was partitioned into linear, quadratic, and cubic components with orthogonal polynomials for all possible combinations of interactions of dates and rates (Table 1). Multiple regression was used to determine the coefficients for the appropriate terms in the interaction, e.g., date quadratic by rate cubic. Data from all 4 applications dates for both years were used to draw the 3-dimensional graphs to display the response surface. Adding data from the fourth application date in 1981 only slightly decreased the $R^{2}$ values and the response surface for the first 3 dates remained nearly the same.

Polynomial equations did not adequately represent the data when there was a significant interaction between date and rate even though $R^{2}$ values ranged from 0.77 to 0.97 . The 3 -dimensional graphs showed a response across application dates for the zero mefluidide rates when there should have been no response. Log and $\log$-log transformations were tested but did not adequately represent the data between the zero and $0.28 \mathrm{~kg}$ rates.

\section{Results and Discussion}

\section{Comparison of Chemicals}

The licensed rates of $\mathrm{MH}(4.5 \mathrm{~kg} / \mathrm{ha}$ a.i. $)$ and $\mathrm{MH}(3.36 \mathrm{~kg} / \mathrm{ha})$ plus chlorflurenol $(1.12 \mathrm{~kg} / \mathrm{ha})$ were used in this study to compare with various rates of mefluidide. The licensed rate of MH plus chlorflurenol was determined by extensive testing on various grass species in both the United States and Canada (Anderson 1970). With one exception, there was no significant difference between MH alone and MH plus chlorflurenol on heading, forage yield, CP, and IVDOMD of crested wheatgrass when applied on 4 application dates in 1981 and 1982 (Table 2). This exception was when MH plus chlorflurenol decreased forage yield more than $\mathrm{MH}$ alone on the first application date in 1981. Stich et al. (1978) also found that application of $5.6 \mathrm{~kg} / \mathrm{ha}$ of $\mathrm{MH}$ decreased heading of red fescue (Festuca rubra L.) similar to application of $3.36 \mathrm{~kg} / \mathrm{ha}$ of MH plus $1.12 \mathrm{~kg} / \mathrm{ha}$ of chlorflurenol. However, Jagschitz et al. (1978) found that addition of chlorflurenol with MH was better than $\mathrm{MH}$ alone in reducing heading in Kentucky bluegrass (Poa pratensis $\mathrm{L}$.) and about equal for the other 4 cool-season grasses.

There were some differences between application of mefluidide at $0.56 \mathrm{~kg} / \mathrm{ha}$ and $\mathrm{MH}$ in 1981 and 1982 on heading, forage yield, $\mathrm{CP}$, and IVDOMD of crested wheatgrass (Table 2). These differences were not consistent across all application dates and may have resulted from sampling error. For example, mefluidide decreased

Table 2. Effect of mefluidide (0.56 kg/ha) (MF), maleic hydrazdde (4.5 kg/ha) (MH) and MH (3.36 kg/ha) plus chlorfluerenol (1.12 kg/ha) (MH+C) on number of heads, forage yield, CP, and IVDOMD of created wheatgrass grown near Sidney, Montan during 1981 and 1982.

\begin{tabular}{|c|c|c|c|c|c|c|c|c|c|c|c|c|}
\hline \multirow[b]{2}{*}{ Appl. date } & \multicolumn{3}{|c|}{ Heads $/ \mathrm{m}^{2}$} & \multicolumn{3}{|c|}{ Forage, $T /$ ha } & \multicolumn{3}{|c|}{$\mathrm{CP}, \%$} & \multicolumn{3}{|c|}{ IVDOMD, $\%$} \\
\hline & MF & MH & $\mathrm{MH}+\mathrm{C}$ & MF & MH & $\mathrm{MH}+\mathrm{C}$ & MF & MH & $\mathrm{MH}+\mathrm{C}$ & MF & MH & $\mathrm{MH}+\mathrm{C}$ \\
\hline $\begin{array}{l}7 \text { Apr. } \\
22 \text { Apr. } \\
4 \text { May }\end{array}$ & $\begin{array}{r}168 \\
15 \\
55 \\
\end{array}$ & $\begin{array}{r}363 \\
97 \\
7 \\
\end{array}$ & $\begin{array}{r}288 \\
99 \\
4 \\
\end{array}$ & $\begin{array}{l}1.78 \\
1.33 \\
1.04 \\
\end{array}$ & $\begin{array}{l}1.82 \\
1.62 \\
1.25 \\
\end{array}$ & $\begin{array}{l}1.50 \\
1.39 \\
1.18 \\
\end{array}$ & $\begin{array}{l}6.6 \\
8.6 \\
8.3 \\
\end{array}$ & $\begin{array}{l}6.9 \\
8.1 \\
8.0 \\
\end{array}$ & $\begin{array}{l}6.6 \\
8.6 \\
8.2 \\
\end{array}$ & $\begin{array}{l}56.4 \\
57.2 \\
55.3 \\
\end{array}$ & $\begin{array}{l}56.0 \\
57.8 \\
54.6 \\
\end{array}$ & $\begin{array}{l}54.7 \\
56.3 \\
54.1 \\
\end{array}$ \\
\hline $\begin{array}{l}\text { LSD }_{.06}^{1} \\
18 \mathrm{May}\end{array}$ & 372 & $\begin{array}{l}122 \\
107 \\
\end{array}$ & 55 & 1.27 & $\begin{array}{l}0.25 \\
1.26 \\
\end{array}$ & 1.32 & 7.4 & $\begin{array}{l}0.9 \\
7.4 \\
\end{array}$ & 7.7 & 53.3 & $\begin{array}{r}1.9 \\
51.4 \\
\end{array}$ & 52.6 \\
\hline LSD.06 & & 166 & & & 0.19 & & & 0.7 & & & 1.5 & \\
\hline $\begin{array}{l}28 \text { Apr. } \\
12 \text { May } \\
25 \text { May } \\
10 \text { June }\end{array}$ & $\begin{array}{r}52 \\
16 \\
170 \\
313 \\
\end{array}$ & $\begin{array}{r}87 \\
23 \\
102 \\
228 \\
\end{array}$ & $\begin{array}{r}54 \\
12 \\
104 \\
240 \\
\end{array}$ & $\begin{array}{l}1.55 \\
1.13 \\
1.07 \\
1.64 \\
\end{array}$ & $\begin{array}{l}1.15 \\
0.94 \\
1.10 \\
1.61 \\
\end{array}$ & $\begin{array}{l}0.95 \\
0.83 \\
1.08 \\
1.59 \\
\end{array}$ & $\begin{array}{l}5.2 \\
6.2 \\
6.3 \\
4.7 \\
\end{array}$ & $\begin{array}{l}6.5 \\
6.9 \\
6.1 \\
4.8 \\
\end{array}$ & $\begin{array}{l}6.7 \\
7.3 \\
6.4 \\
4.7 \\
\end{array}$ & $\begin{array}{l}59.7 \\
59.7 \\
56.8 \\
54.3 \\
\end{array}$ & $\begin{array}{l}59.2 \\
54.9 \\
57.2 \\
57.1 \\
\end{array}$ & $\begin{array}{l}58.1 \\
56.3 \\
59.0 \\
56.1 \\
\end{array}$ \\
\hline LSD. $.06^{1}$ & & 95 & & & 0.22 & & & 0.6 & & & 1.9 & \\
\hline
\end{tabular}

ILSD of interaction 

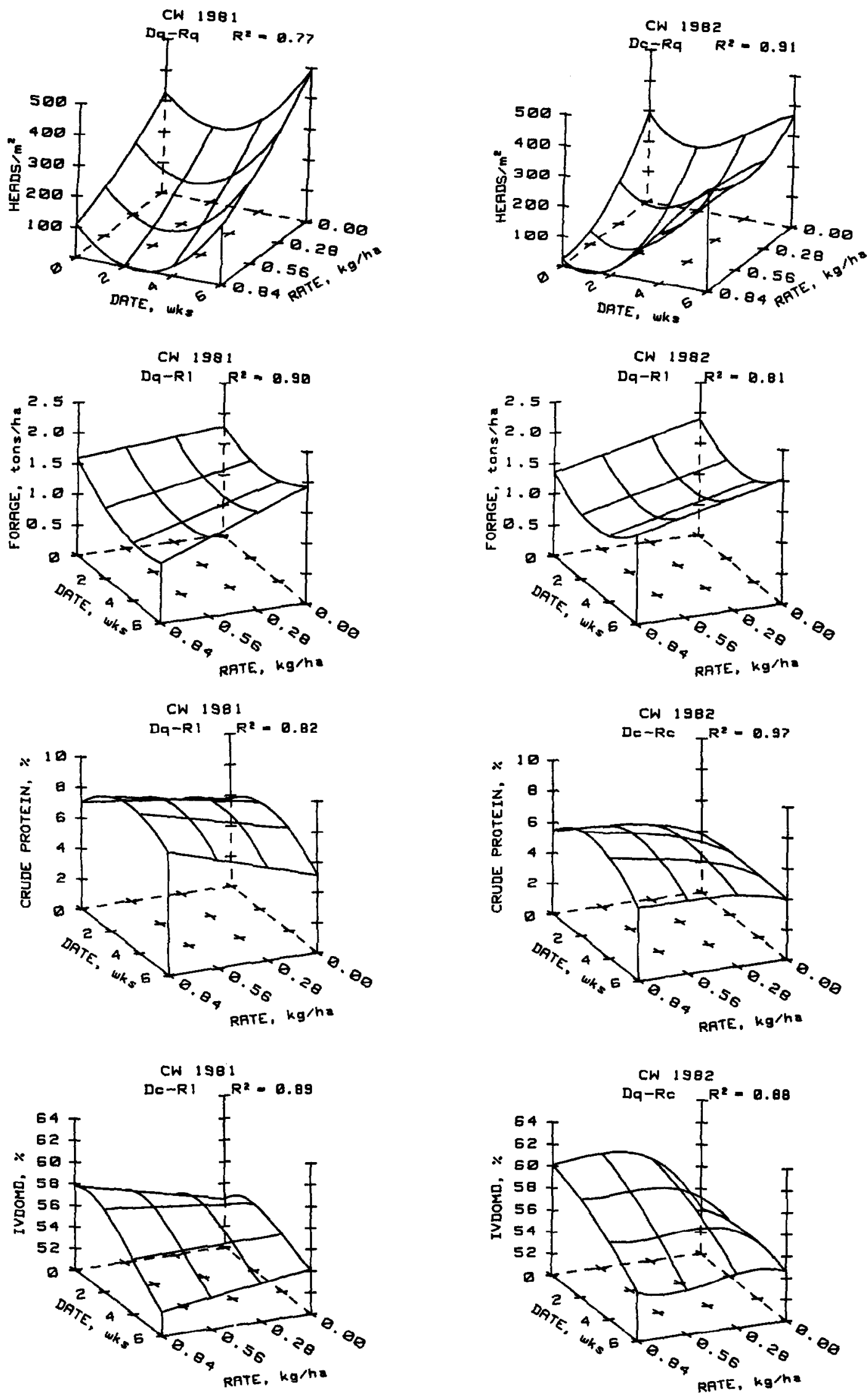

Fig. 1. Effects of date (weeks after floral primordium initiation) and rate of mefluidide application on heads, forage yield, CP, and IVDOMD of crested wheatgrass grown near Sidney, Mont., during 1981 and 1982. The interaction terms used in plotting each response surface are listed on the graph, e.g. $D q-R q, D=$ date, $R=$ rate, $l=$ linear, $q=$ quadratic, and $c=$ cubic. 
heading more than MH the first application date and less the last date in 1981 but no difference was noted the next year. Mefluidide reduced forage yield more than $\mathrm{MH}$ the second application date in 1981 but less than MH the first date in 1982. Mefluidide increased $\mathrm{CP}$ less than $\mathrm{MH}$ the first and second application dates in 1982 but not in 1981. Mefluidide also increased IVDOMD more than MH the last date in 1981 but less than $\mathrm{MH}$ the last date in 1982. Jagschitz et al. (1978) also found that mefluidide and MH were similar in reducing heading of 5 cool-season grasses. Stich et al. (1978) found that $\mathrm{MH}$ at $5.6 \mathrm{~kg} / \mathrm{ha}$ was similar to $0.42 \mathrm{~kg} / \mathrm{ha}$ of mefluidide in controlling heading of red fescue.

\section{Date of Mefluidide Application}

There was a significant date by rate interaction for mefluidide both years (Table 1). Application of mefluidide 2 to 4 weeks after floral primordium initiation in 1981 was most effective in reducing heading of crested wheatgrass but in 1982 it was most effective 2 weeks earlier (Fig. 1).

Why growth regulators were more effective reducing crested wheatgrass heading on the first application date in 1982 than in 1981 is unclear. Growth regulators were applied both years within the same week that the first floral primordium was initiated; at that time, leaf height was about $10 \mathrm{~cm}$. Mefluidide was applied the first, second, third, and fourth application dates when 126, 229, 357, and 493 degree days had been accumulated the first year, and when 132 , 237,373 , and 551 degree days had been accumulated the second year, respectively. Accumulated degree days were more nearly the same both years for the first 2 dates than the last 2 dates. The fourth application of mefluidide was made when crested wheatgrass was $1 \%$ and $20 \%$ headed the first and second years, respectively.

It does not appear that precipitation following application of growth regulators affected their effectiveness. During the first year, precipitation was received $5(2 \mathrm{~mm}), 5(2 \mathrm{~mm}), 4(2 \mathrm{~mm})$, and 5 (5 $\mathrm{mm}$ ) days after application of growth regulators when applied 0,2 , 4, and 6 weeks after floral primordium initiation, respectively. During the second year, precipitation was received 10 (2 $\mathrm{mm}), 3$ (13 $\mathrm{mm}), 2$ (25 $\mathrm{mm})$, and $17(23 \mathrm{~mm})$ days after application of growth regulators when applied $0,2,4$, and 6 weeks after floral primordium initiation, respectively. The mefluidide label states that optimum results may not be obtained if precipitation occurs within $8 \mathrm{hr}$ following application and this did not happen.

Others have found that date of mefluidide application on perennial ryegrass (Field and Whitford 1982), annual bluegrass [Poa annua var. reptans (Hauskins) Timm.] (Danneberger et al. 1987, Jagschitz 1985), tall fescue (Festuca arundinacea Schreb.) (Gerrish and Dougherty 1983), and foxtail barley (Hordeum jubatum L.) (White 1984) had a significant effect on head control. However, most researchers have applied mefluidide a few days after mowing of turf grasses (Hield et al. 1979), Field and Whitford 1980, Jackson et al. 1980) or on some calendar date with no measure of plant growth stage (Fales et al. 1976, Jagschitz et al. 1978, Robb et al. 1983, Glenn et al. 1987). However, White (1984) found that mefluidide was most effective in controlling heading of foxtail barley when applied near initiation of floral primordia. It appears from this study that mefluidide was most effective in reducing heading of crested wheatgrass when applied from 0 to 2 weeks after initiation of floral primordia. This would be 4 to 6 weeks before appearance of the seed heads. The optimum time for application of mefluidide to crested wheatgrass is less than that suggested on the mefluidide label. Label instructions state that maximum benefits can be attained by applying mefluidide at any time between uniform green up in the spring until 2 weeks before seed head appearance.

Mefluidide reduced August forage yield (Fig. 1) most when applied 2 to 6 weeks after floral primordium initiation in 1981 and 2 to 4 weeks after initiation in 1982. This was 2 weeks later than the most effective date for reducing heading. Mefluidide was most effective in increasing CP (Fig. 1) both years when applied 2 to 4 weeks after floral primordium initiation. In contrast mefluidide was most effective in increasing IVDOMD (Fig. 1) both years when applied 0 to 2 weeks after flora initiation.

Indices other than the initiation date of crested wheatgrass floral primordia could be used to determine when to apply mefluidide. For example, in both years Hood's phlox (Phlox hoodii Richardson) first flowered the same week that crested wheatgrass floral primordium was initiated. Common dandelion (Taraxacum officinale Weber) first flowered a week later.

\section{Rate of Mefluidide Application}

Mefluidide rates from 0 to $0.84 \mathrm{~kg} /$ ha decreased heads quadratically and forage yield linearly both years (Fig. 1). Mefluidide increased CP and IVDOMD linearly the first year but cubicly the second year (Fig. 1).

In 1982, application of only $0.28 \mathrm{~kg} /$ ha of mefluidide within 0 to 2 weeks after floral primordium initiation reduced crested wheatgrass seed heads by over $90 \%$ and increased forage quality. However, in 1981, a similar response required application of $0.56 \mathrm{~kg} / \mathrm{ha}$ of mefluidide. Application of $0.56 \mathrm{~kg} / \mathrm{ha}$ of mefluidide 2 weeks after floral primordium initiation decreased heading 80 and $95 \%$, decreased forage yield 22 and $31 \%$, increased CP 1.7 and 2.3 percentage units, and increased IVDOMD 1.8 and 4.2 percentage units in 1981 and 1982, respectively.

Morre and Tautvydas (1986) also found that application of successively higher rates of mefluidide to tall fescue caused a curvilinear decrease in heads. The response surface and magnitude of various rates of mefluidide on heading, forage yield, CP, and IVDOMD of crested wheatgrass was very similar to that reported by Haferkamp et al. (1987). They also found that heading, yield, and quality response varied from linear to curvilinear depending upon the year.

The effects of mefluidide might have been more consistent if a nonionic surfactant had been applied with it. Jackson et al. (1980) and Morre and Tautvydas (1986) found that application of a nonionic surfactant at 0.25 to $0.5 \% \mathrm{~V} / \mathrm{V}$ with mefluidide enhanced its effectiveness, while Jagschitz et al. (1978) found no such effect. The mefluidide label originally prohibited additions of adjuvants such as surfactants, spreaders, stickers, etc. The label now states that nonionic surfactant be used at 0.25 to $0.5 \%$ volume/volume of tank mixture. If surfactant addition was as effective as reported by Morre and Tautvydas (1986), the $0.28 \mathrm{~kg}$ / ha mefluidide rate could have provided over $90 \%$ control of heading in 1981 . This would reduce chemical cost by half.

\section{Conclusions}

Future research on improving forage quality with growth regulators should be concentrated on mefluidide. Mefluidide will be licensed for use on tall fescue in 1989, and this license may later be extended to crested wheatgrass. Maleic hydrazide or $\mathrm{MH}$ plus chlorflurenol will probably not be licensed for such use because of residue problems. The application of $4.5 \mathrm{~kg} / \mathrm{ha}$ of $\mathrm{MH}$ had no consistent benefit over application of $0.56 \mathrm{~kg} /$ ha of mefluidide at 4 growth stages. Application of $3.36 \mathrm{~kg} / \mathrm{ha}$ of $\mathrm{MH}$ plus $1.12 \mathrm{~kg} / \mathrm{ha}$ of chlorflurenol at $4 \mathrm{growth}$ stages had no beneficial effects on forage yield or quality in comparison with $\mathrm{MH}$ alone.

Mefluidide was more effective in decreasing heading and increasing CP and IVDOMD when applied 0 to 2 weeks after inititation of first floral primordium. The accumulation of degree days or initiation of first floral primordium can be used to determine when to apply mefluidide most effectively to crested wheatgrass. Application of $0.56 \mathrm{~kg}$ / ha of mefluidide 0 to 2 weeks after floral primordium initiation was the most effective treatment in reducing heading and increasing forage quality. Further research is needed to determine what date and rate mefluidide should be applied to crested wheatgrass to optimize beef gains per hectare. In 
order to increase beef gains per hectare mefluidide needs to be applied when it will maximize IVDOMD increases and minimize forage yield decreases.

\section{Literature Cited}

Anderson, D.0. 1970. Growth retardant chemicals. Ohio State Univ. Short Course Roadside Develop. 29:93-97.

Campbell, J.B. 1961. Continuous versus repeated-seasonal grazing of grass-alfalfa mixtures at Swift Current, Saskatchewan. J. Range Manage. 14:72-77.

Danneberger, T.K., B.E. Branham, and J.M. Vargas, Jr. 1987. Mefluidide applications for annual bluegrass seedhead suppression based on degreeday accumulation. Agron. J. 79:69-71.

Fales, S.L., A.P. Nielsen, and R.C. Wakefield. 1976. Top growth and root growth response of red fescue to growth retardants. Proc. N.E. Weed Sci. Soc. 30:334-339.

Field, R.J., and A.R. Whitford. 1980. The effect of mefluidide on the growth of perennial ryegrass. Proc. 33rd New Zealand Weed and Pest Control Conf. 33:74-78.

Field, R.J., and A.R. Whitford. 1982. The retardation of grass growth by synthetic plant growth regulators. p. 485-504. In: J.S. McLaren (ed.). Chemical Manipulation of Cop Growth and Development. Butterworths, London.

Gerriah, J.R., and C.T. Dougherty. 1983. Tall fescue sward response to mefluidide and nitrogen. Agron. J. 75:895-898.

Glenn, B.P., J. Bond, and S. Glenn. 1987. Effects of mefluidide treatment, nitrogen fertilization, and tall fescue variety on nutrient metabolism by growing sheep fed fall-harvested silages. J. Anim. Sci. 65:797-807.

Haferkamp, M.R., R.F. Miller, and F.A. Sneva. 1987. Mefluidide effects on forage quality of crested wheatgrass. Agron. J. 79:637-641.
Hield, H., S. Hematreet, V.A. Gibeault, and V.B. Youngner. 1979. Warm season turf growth control with Embark. California Agr. 33:(10)15-16.

Jackeon, I.F., B.P. O'Connor, and D.J.I. Jacobson. 1980. Mefluidide: A plant growth regulator. Proc. 33rd New Zealand Weed and Pest Control Conf. 33:67-73.

Jafachitz, J.A. 1985. Mefluidide timing for Poa annua L. seedhead suppression. Proc. N.E. Weed Sci. Soc. 39:268-269.

Jagachitz, J.A., J.D. Stich, and R.C. Wakefield. 1978. Effect of growth retardants on cool season lawn grasses. Proc. N.E. Weed Sci. Soc. 32:319-327.

Morre, D.J., and K.J. Tautvydas. 1986. Mefluidide-chlorsulfuron-2,4-D surfactant combinations for roadside vegetation management. J. Plant Growth Regul. 4:189-201.

Robb, T.W., D.G. Ely, C.E. Rieck, S. Glemn, L. Kitchen, B.P. Glenn, and R.J. Thomas. 1983. Beef production from tall fescue treated with mefluidide, a chemical plant-growth regulator. p. 725-728. In: J.A. Smith and V.W. Hays (ed.). Proc. XIV Int. Grassland Congr.

Stich, J.D., R.C. Wakefield, and J.A. Jagachitz. 1978. Combinations of growth retardants and broadleaf herbicides for roadside turf-grass. Proc. N.E. Weed Sci. Soc. 32:328-331.

Wakefield, R.C., and A.T. Dore. 1973. Growth control for highway turf. Proc. 2nd Int. Turfgrass Res. Conf. p. 569-576.

White, L.M. 1984. Foxtail barley heading, yield, and quality as influenced by growth regulators and a desiccant. Agron. J. 76:27-30.

White, LM., G.P. Hartman, and J.W. Bergman. 1981. In vitro digestibility, crude protein, and phosphorus content of straw of winter wheat, spring wheat, barley, and oat cultivars in eastern Montana. Agron. J. 73:117-121.

White, L.M., and J.R. Wight. 1981. Seasonal dry matter yield and digestiblity of seven grass species, alfalfa, and cicer milkvetch in eastern Montana. Agron. J. 73:457-462.

\title{
Range Research: Basic Problems and Techniques
}

\author{
editors: C. Wayne Cook and James Stubbendieck
}

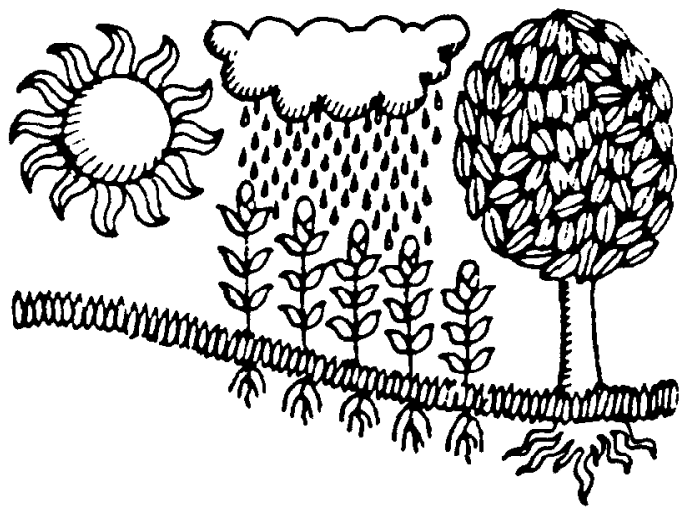

RANGE RESEARCH: BASIC PROBLEMS AND TECHNIQUES, a major revision of an earlier publication of the National Academy of Science, presents steps in research planning, evaluation of results, and methods and procedures in range research, including sampling techniques and experimental design. Chapter titles include: The Range Research Problem, Assessment of Habitat Factors, Methods of Studying Vegetation, Studies of Root Habits and Development, Methods of Measuring Herbage and Browse Utilization, Livestock Selection and Management in Range Research, Methods for Studying Rangeland Hydrology, Economic Research in Range Management, Sampling Methods with Special Reference to Range Management, Experimental Design, and Problems Involved in the Application of Research Techniques in Range Management. The book is designed to serve as a reference guide for range research methodology and as a textbook for advanced students who anticipate careers in this increasingly important field. 1986. 336 pages ISBN 09603692-3-6. \$28/hard.

Society for Range Management

1839 YORK STREET • DENVER. COLORADO $80206 \bullet$ USA 